\title{
GRAVE OF THE CORDED WARE CULTURE FROM WĘGRZCE, KRAKÓW DISTRICT
}

\author{
Maciej NowaK ${ }^{1}$, Barbara Musial--_aczeK ${ }^{2}$, Piotr WlodarczaK ${ }^{3}$
}

A u t h o r s' a d d r e s s e s: 1 - Pracownia Archeologiczna Maciej Nowak, e-mail: archeomaciek@ gmail.com, ORCID: 0000-0003-4960-6049; 2 - Independent researcher, e-mail: b.musial_laczek@vp.pl, ORCID: 0000-0002-6359-2141; 3 - Institute of Archaeology and Ethnology, Polish Academy of Sciences, Sławkowska 17, 31-016 Kraków, Poland, e-mail: wlodarczak.piotr@gmail.com, ORCID: 00000003-0359-7386.

A b s t r a c t. Grave 3/2016 from site 3 in Węgrzce, Comm. Zielonki, Kraków District was discovered during archaeological excavations preceding construction of a detached house. This was a niche grave, holding two burials: a male aged $38-47$ years, and a child 4-5 years old. The recorded funeral rite is characteristic of a cluster of Corded Ware culture cemeteries on the lower Dłubnia River, near Kraków. A vessel recovered from the grave reveals local features characteristic of that cluster. One radiocarbon age determination was obtained for the burial, pointing to ca. 2470-2350 BC as the most likely range. Thus, the grave links with the younger phase of the Final Eneolithic in Lesser Poland.

K e y w o r d s: Corded Ware culture, Final Eneolithic, Lesser Poland, chronology, burial custom

\section{INTRODUCTION}

In the Kraków region, Final Eneolithic cemeteries (ca. 2900-2300 BC) form a distinct cluster on the lower Dlubnia. The first discoveries date back to the 19th century, with a burial from Węgrzce, Comm. Zielonki, discovered not far from the customs house in Michałowice, being one of the oldest examples (KIRKOR 1881) ${ }^{1}$. Most of the finds in this area come from research carried out in connection with industrialization: the construction of steel works in Nowa Huta and other large projects. In total, 19 sites are known from the discussed area, in which 46 or 47 grave assemblages were found (WŁodARCZAK 2020). The grave from site 3 in Węgrzce, which is the focus of this paper, belongs to a small group of discoveries already made in the $21^{\text {st }}$ century. It comes from rescue research carried out in connection with the construction of

1 The location of the discovery was incorrect - in fact, it comes from site 9 at Bosutów, Comm. Zielonki.

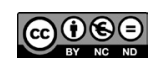


a detached house. It is a valuable addition to the list of sepulchral features from the Kraków region, especially given that the documentation of most of the graves known from the region is fragmentary and does not provide good data for studies on the Final Eneolithic funeral rite.

Site 3 in Węgrzce is located north of Kraków, on the culmination of a loess plateau with an absolute height of $287.8 \mathrm{~m}$ above sea level, rising above the valley of Sudó stream (a right-bank tributary of the Dłubnia). This area is the western periphery of the Proszowice Upland, also known as the Proszowice Plateau, bordering with the Ojców Plateau. The predominant feature of the upland landscape is wide humps with flat or rounded tops (GilewsKa, Starkel 1980). The area has an almost continuous loess cover, on which fertile chernozem soils have developed (KONDRACKI 2002), with underlying tills of the Kraków (Mindel) glaciation (GiLewska, Starkel 1980).

The site was discovered during a field trip by Piotr Bielenin and Jerzy Talaga, employees of the Archaeological Museum in Kraków. In a note dated 7 April 1950, they describe it as follows: "... we went to a perfectly visible hill, some 500 metres off the road, on the edge of which, on the left, a tall oak cross stands by a dirt road...". There, in German trenches dating back to World War II which had still not been filled back by that time, they discovered archaeological features and fragments of vessels of the Baden culture, and perhaps of the Funnel Beaker culture as well. Attached to the note is a topographical sketch showing the locations of the trenches from 1944, the places where archaeological features were discovered, along with drawings of the most characteristic artefacts.

Originally, the range of the site, referred to as "Węgrzce A", was marked as encompassing the southern and south-western slopes of a prominent hill rising above the historic centre of the village. Surface surveys carried out as part of the Polish Archaeological Record programme in 2008 allowed a new, much wider range to be determined, including the hilltop parts as well (Fig. 1) (research by Jacek Górski and Mirosław Zając). ${ }^{3}$

Currently, due to the attractive location in the vicinity of the Krakow agglomeration, development of detached houses is gradually spreading to the area. It was in connection with this type of construction that rescue excavations were carried out in 2016. In the explored area of $220 \mathrm{~m}^{2}, 13$ objects dating from the Neolithic to the $20^{\text {th }}$ century were identified. The most spectacular discovery turned out to be a grave of the Corded Ware culture (CWC) with the burial of a man and a child, which is the subject of this study.

\footnotetext{
2 A note in the archive of the Archaeological Museum in Kraków.

3 It is worth mentioning here the problems with the protection of the site. They stem from the fact that the local development plan for the Zielonki commune only takes into account the originally marked range of the site. At the same time, the new range does not fully overlap with the actual area where artefacts occur on the surface, either.
} 


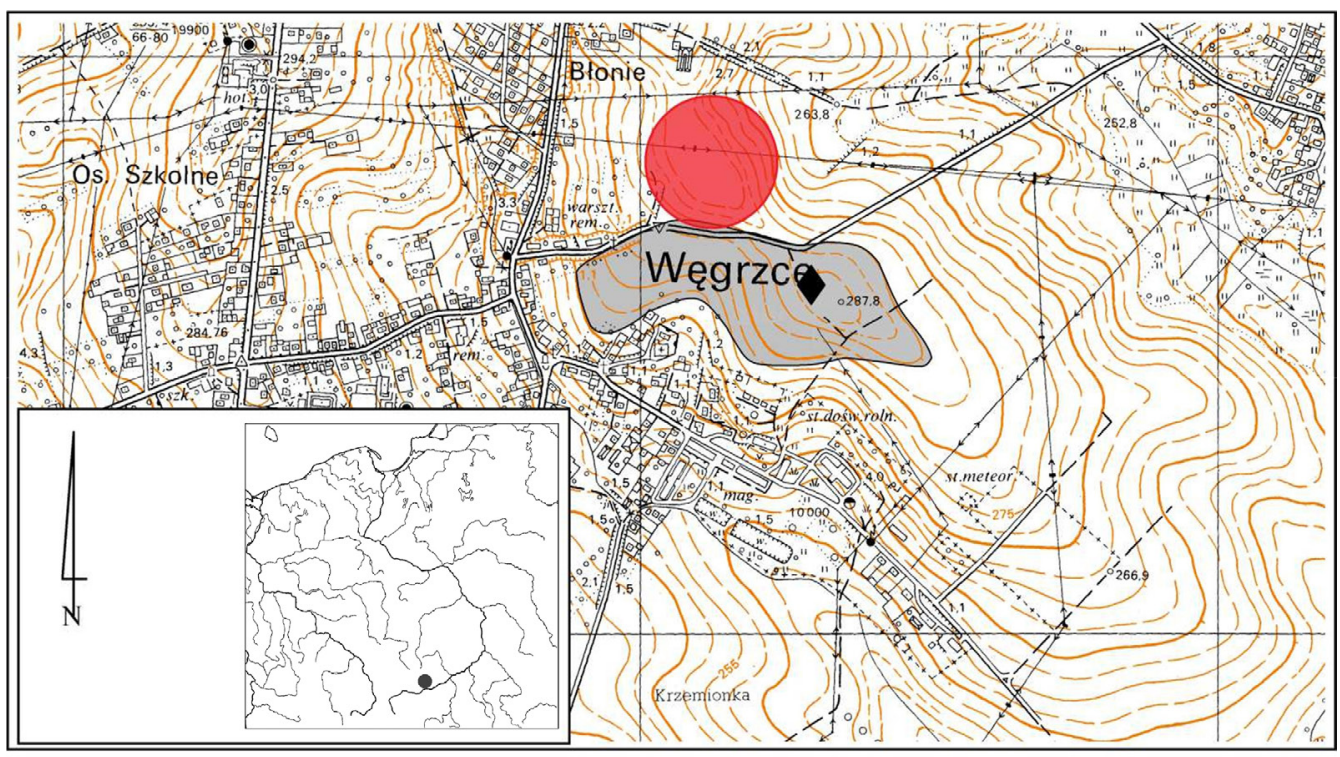

A

B

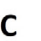

Fig. 1. Location of site no. 3 at Węgrzce, Kraków district. A - range of the archival site of Węgrzce A; $\mathrm{B}$ - range of site no. 3 determined using the Polish Archaeological Record research; C - location of archaeological trench from 2016 (prepared by M. Nowak)

\section{GRAVE DESCRIPTION}

\section{Grave construction}

The grave was discovered in the SE part of the trench (Fig. 2), beneath the bottom of a $25-30 \mathrm{~cm}$ thick humus layer. It was oval in plan, $185 \times 105 \mathrm{~cm}$, with a relatively homogenous fill of dark-brown humic soil. The preserved depth of the grave was merely $30 \mathrm{~cm}$, which testifies to a considerable destruction of the site (confirmed by the state of preservation of other explored features). The burial was found at the grave's bottom (60 $\mathrm{cm}$ beneath the ground surface).

\section{Burial}

The adult individual was lying in a contracted position on the back, with legs leaning to the right. The left arm was stretched along the body (Fig. 3), while the position of the right arm was secondarily disturbed by the displacement of the forearm bones. Most likely, it was originally bent slightly in the elbow, which the hand pointing towards the pelvis or waist.

The poorly preserved burial of a child 4-5 years of age was found to the east of the adult skeleton (Fig. 3). The arrangement of the surviving bone remains suggests 


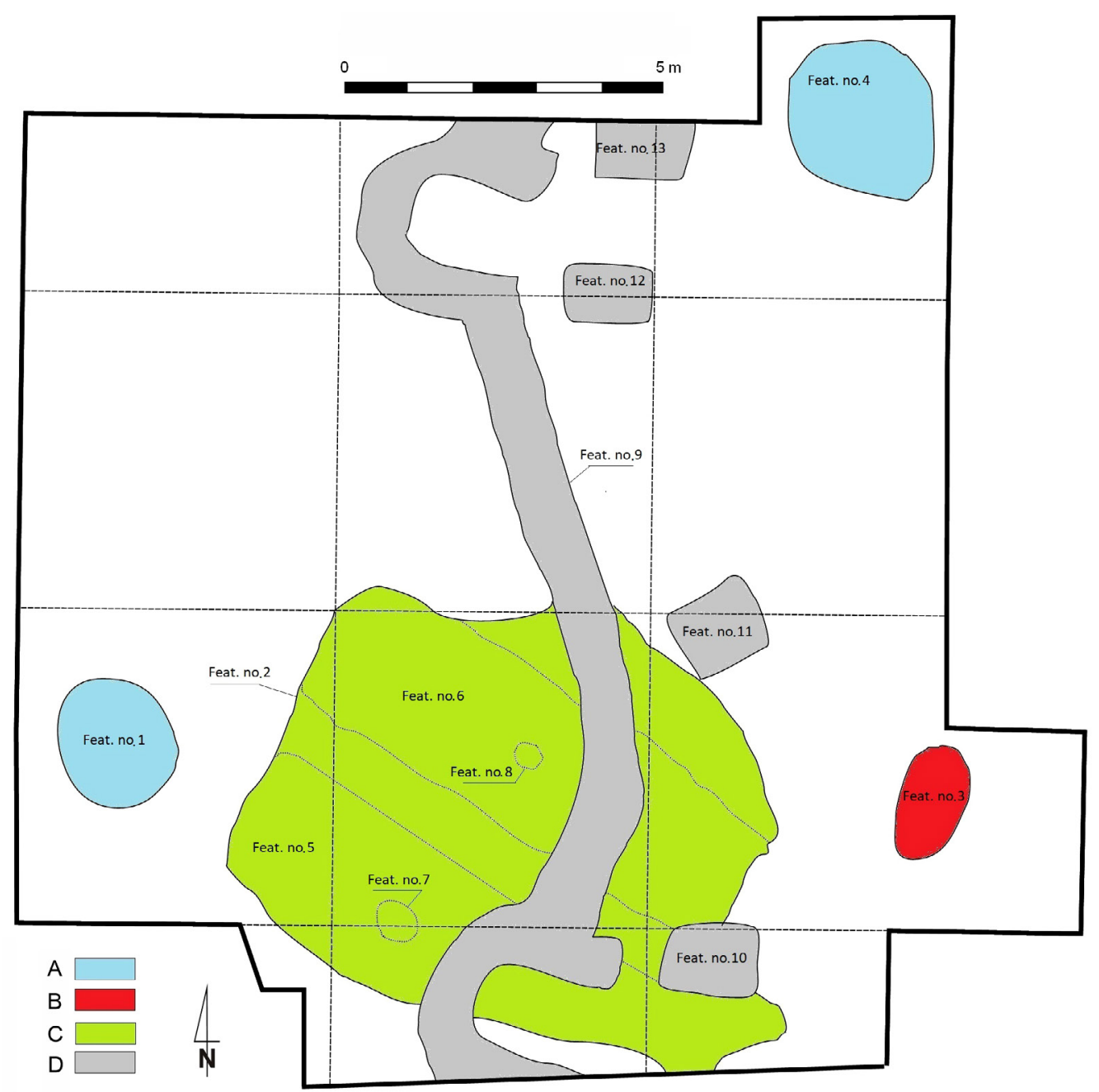

Fig. 2. Węgrzce, Kraków district site no. 3. Excavation plan. A - features dated to Neolithic period; B - feature 3/2016 (grave of the CWC); C - features of undetermined chronology (early Iron Age?); D - trenches from World War II, probably mentioned by K. Bielenin and J. Talaga in 1950 (illustrated by M. Nowak)

the child was buried in a contracted position on its left side, and oriented along the $\mathrm{N}-\mathrm{S}$ axis, with the head to the S. One can only guess (judging from the position of the long bones and the skull) that the child was buried facing the adult.

The grave goods were placed by the burial of the adult male. A beaker (Fig. 3: 1; Figs 4, 5) was found below the legs, and a stone battle axe (Fig. 3: 2; Fig. 6) by the left shoulder. A bone tool (Fig. 3: 3; Fig. 7: 1) was discovered to the west of the pelvis. In addition, a flint tool and three flakes (Fig. 7: 2-5) were discovered close to the deceased. 

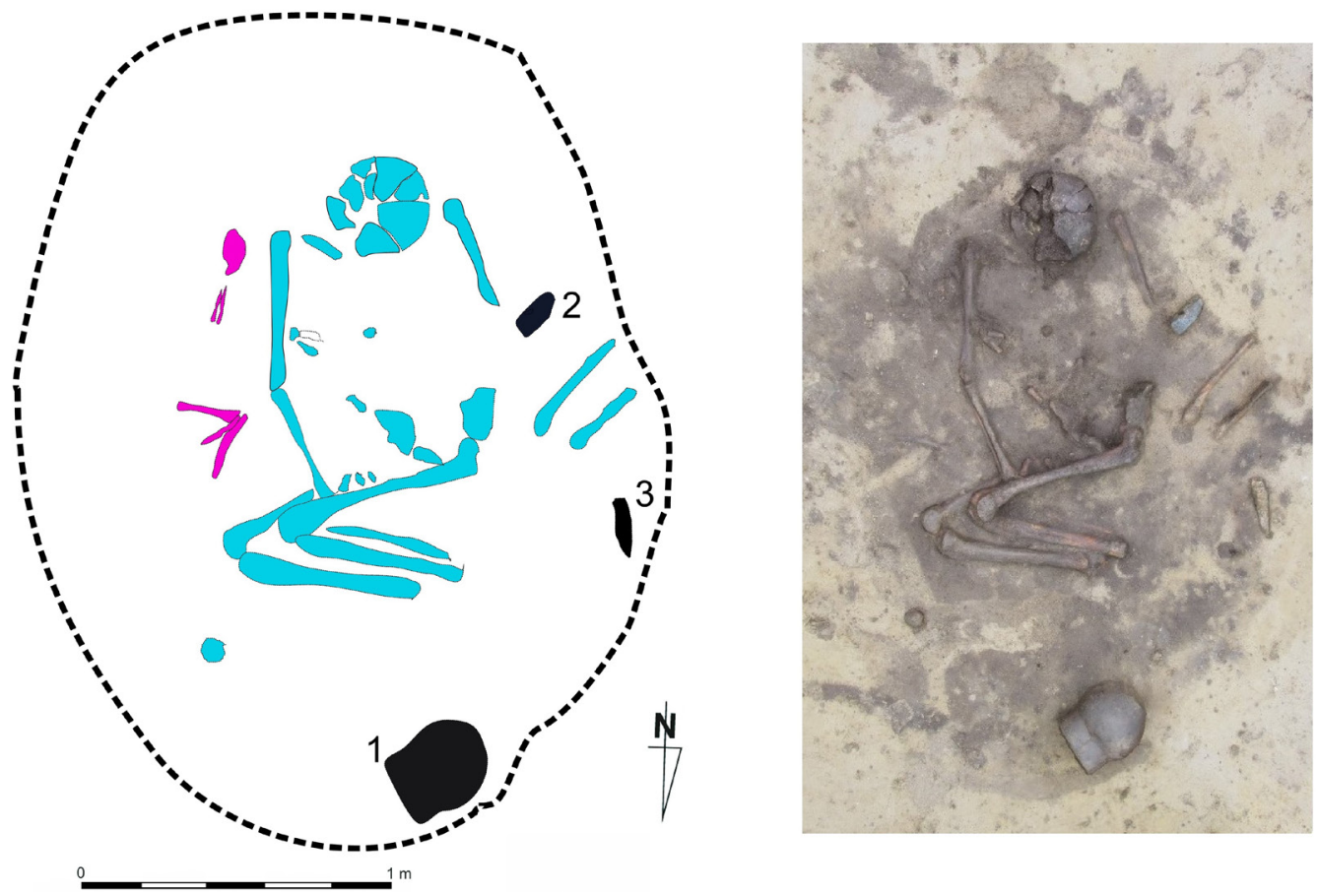

Fig. 3. Węgrzce, Kraków district, site no. 3. Feature no. 3/2016 - burial level. 1 - ceramic beaker, 2 - stone battle axe, 3 - bone awl (illustrated by M. Nowak)

\section{INVENTORY}

1. A two-segment beaker (Fig. 4) with a clearly marked border between the neck and the body. The neck is slightly funnel-shaped and ends with a rim with a thickened, rounded lip. The body is spherical, and the base is not separated and flat. The outer surface is orange-brown, even, matt, and the inner surface is dark grey, even, matt (better smoothed than the outer surface). The wall is two-colour, orange-grey, in cross-section, slightly layered. Scarce admixture: crushed stone and grog. Decoration: in the upper part of the neck, four rows of horizontal s-twisted impressions of a cord $1.3 \mathrm{~mm}$ thick and a band of triple triangular impressions made with a slightly thinner cord, also s-twisted, $1.1 \mathrm{~mm}$ thick (Fig. 5). Dimensions: height $-21.3 \mathrm{~cm}$, rim diameter $-14.3 \mathrm{~cm}$, base diameter $-6.6 \mathrm{~cm}$, belly diameter $-18.9 \mathrm{~cm}$, wall thickness $-0.6 \mathrm{~cm}$.

2. Serpentinite battle axe (Fig. 6), slightly damaged in the butt part. The hole drilled from both sides, situated close to the blade part. The upper side has been carefully flattened. The blade is clearly asymmetrical. The axe is horseshoe-shaped in cross-section. Dimensions: length $-11.4 \mathrm{~cm}$, height $-4.0 \mathrm{~cm}$, width $-4.3 \mathrm{~cm}$, blade width $-4.3 \mathrm{~cm}$, butt width $-2.5 \mathrm{~cm}$, butt height $-2.6 \mathrm{~cm}$, hole diameter $-1.9-2.1 \mathrm{~cm}$.

3. Poorly preserved bone tool resembling a massive awl (Fig. 7: 1), made from a long bone of an unidentified animal. Dimensions: length $-16.4 \mathrm{~cm}$, width at the base $-3.6 \mathrm{~mm}$. 


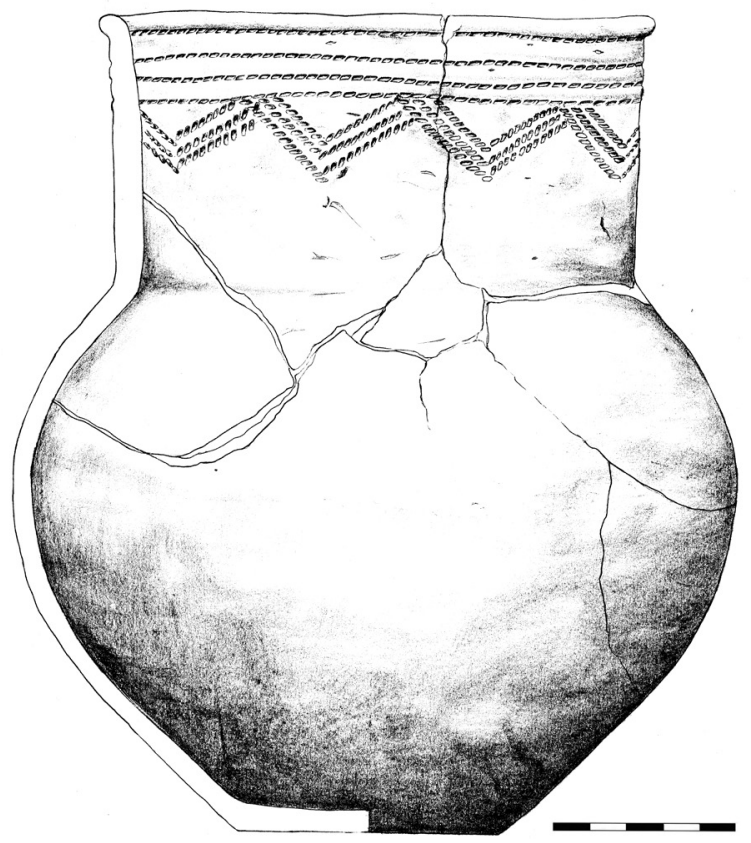

Fig. 4. Węgrzce, Kraków district, site no. 3. Feature no. 3/2016. Grave inventory: beaker (illustrated by Z. Demchuk)

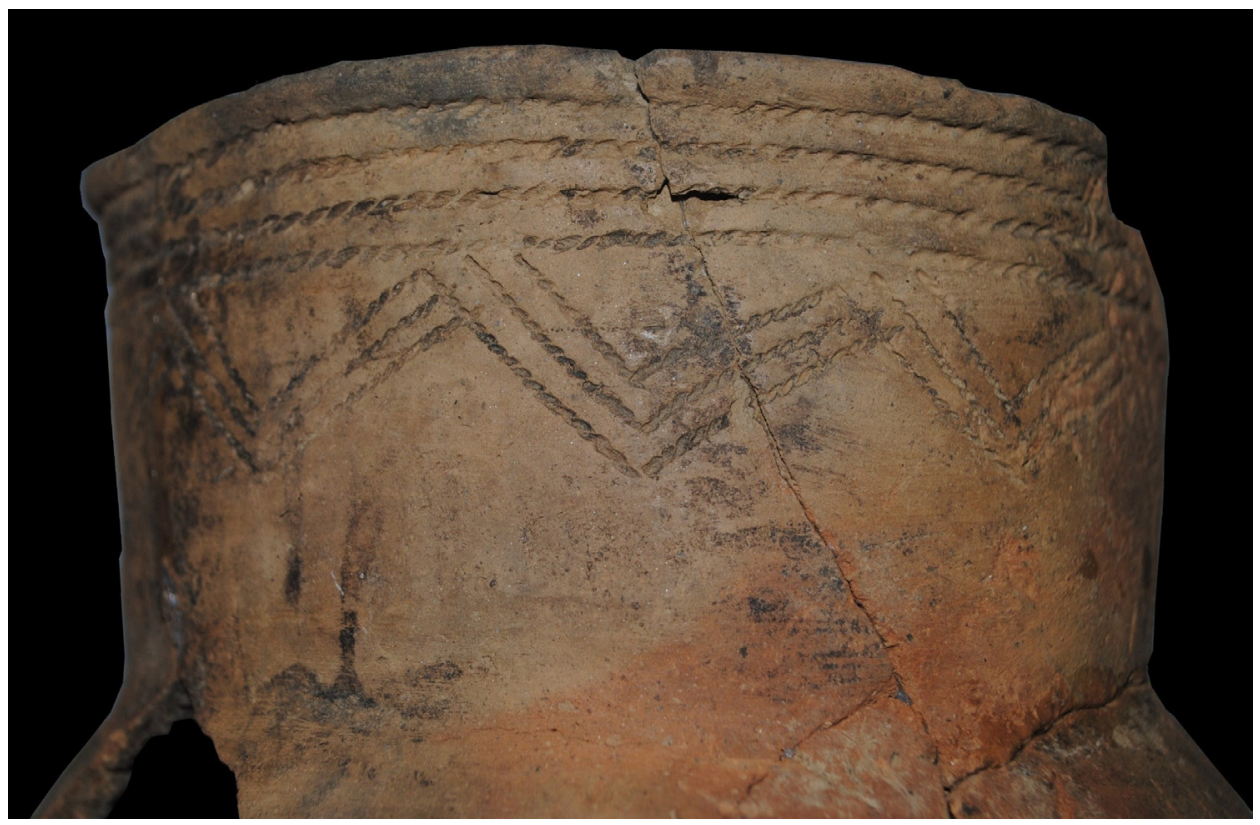

Fig. 5. Węgrzce, Kraków district, site no. 3. Feature no. 3/2016. Ornamented neck of beaker from grave inventory (photo by M. Nowak) 

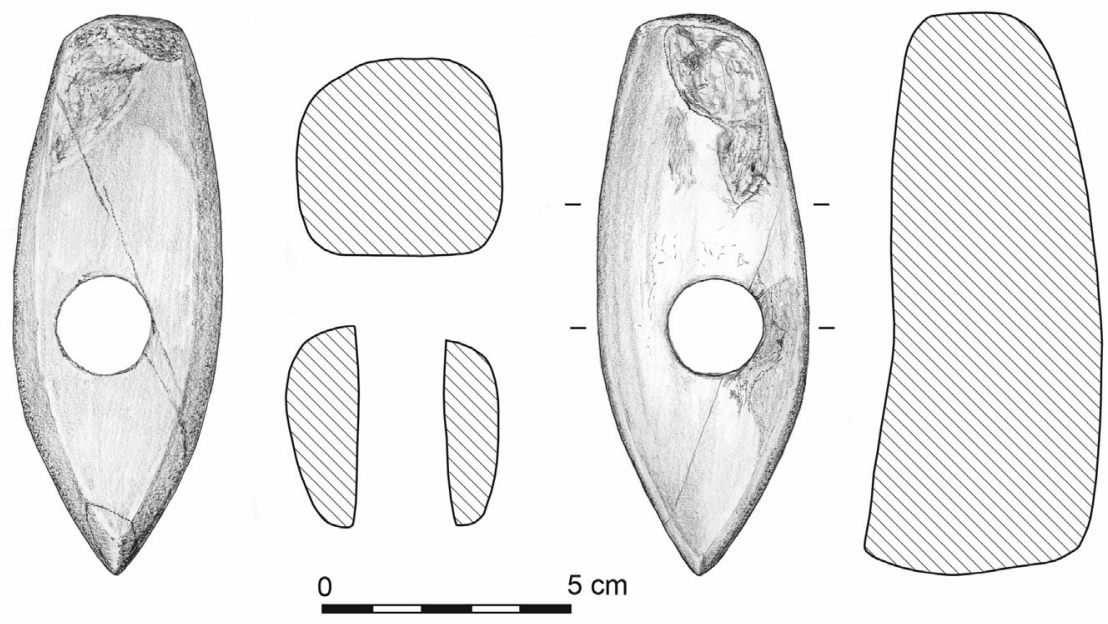

Fig. 6. Węgrzce, Kraków district, site no. 3. Feature no. 3/2016. Grave inventory: stone battle axe (illustrated by E. Włodarczak)

4. Knife insert (Fig. 7: 2) made on a flake of a Kraków Jurassic flint (in typological terms: micro-scraper). Regular, flat retouch on the positive side. Most of the negative side is covered with negatives of removals, with single crushed places at the butt. The butt is prepared. Dimensions: $26 \mathrm{~mm} \times 29 \mathrm{~mm} \times 6 \mathrm{~mm}$.

5. Flake (Fig. 7: 3) of Jurassic Kraków flint, with traces of multi-directional removals on the negative side. Punctiform butt. The bulb is pronounced, with a scar. Dimensions: $34 \mathrm{~mm} \times 16 \mathrm{~mm} \times 6 \mathrm{~mm}$.

6. Fragment of flake (Fig. 7: 4) of Jurassic Kraków flint, with natural, eolised surface preserved on the negative side. Linear butt. Dimensions: $27 \mathrm{~mm} \times 16 \mathrm{~mm} \times 3 \mathrm{~mm}$.

7. Fragment of flake (Fig. 7: 5) of Jurassic Kraków flint, with a negative of a crossed removal on the dorsal side. Prepared butt. Dimensions: $20 \mathrm{~mm} \times 24 \mathrm{~mm} \times 7 \mathrm{~mm}$.

\section{ANALYSIS OF HUMAN SKELETAL REMAINS}

Two skeletons were retrieved from the grave, belonging to an adult and a child.

The preserved bones of the adult skull include the following: the cranial vault without the base of the skull; the mandible without the right ramus and a fragment of the body, with teeth in the preserved fragment (Fig. 8); the left zygomatic bone with a fragment of the maxilla and a premolar (P2) and molars (M1, M2, M3). Based on tooth wear according to Brothwell (1967), the age at death was estimated at 35-45 years. Strong tartar is visible. Periodontitis is severe, which is a feature correlated with age.

Based on the degree of obliteration of the cranial sutures (Fig. 9), the age at death can be estimated at 38-47 years (maturus). 


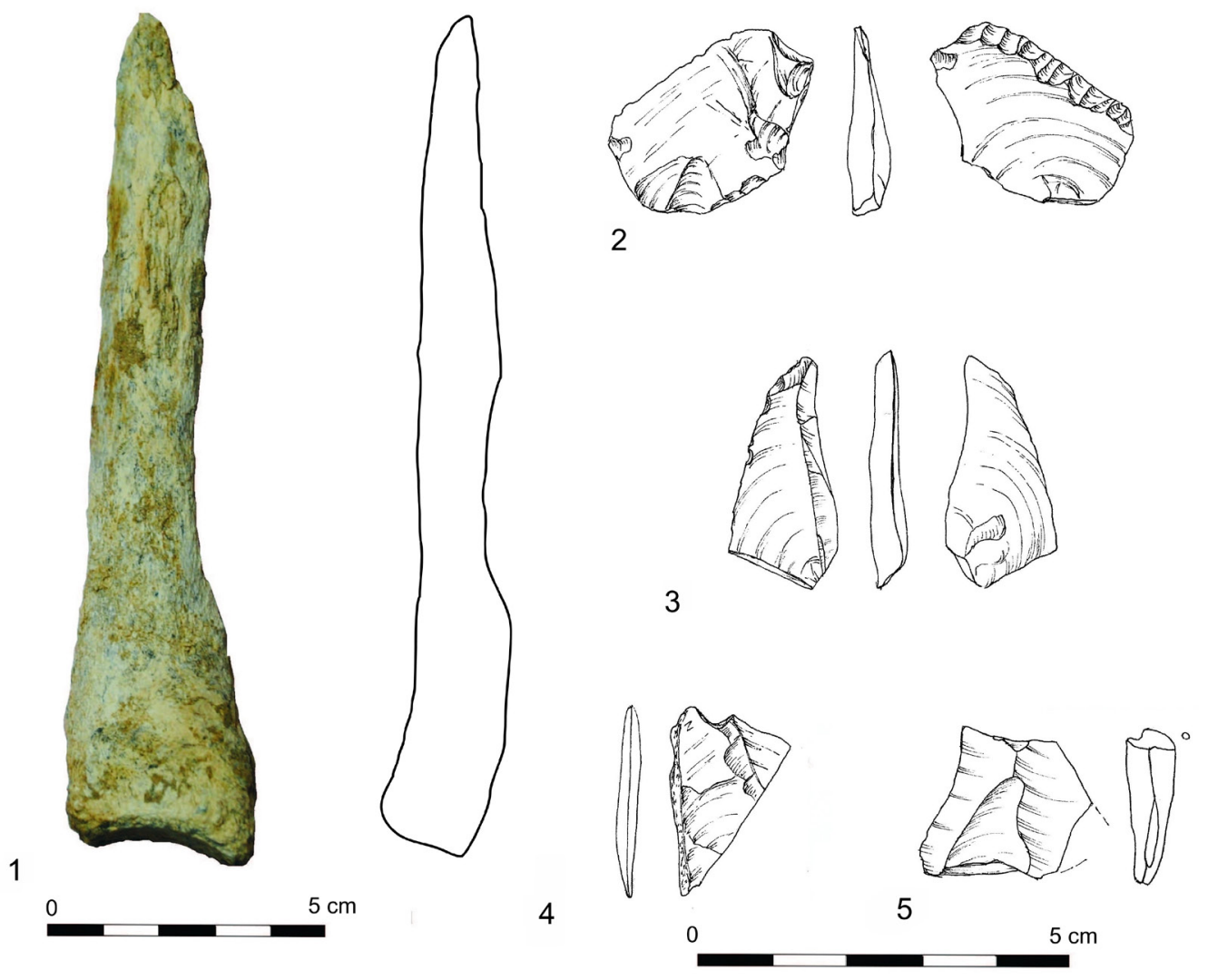

Fig. 7. Węgrzce, Kraków district, site no. 3. Feature no. 3/2016. Grave inventory: 1 - bone awl, 2-5 flint artefacts (illustrated by A. Dziedzic, photo by M. Nowak)

The relief of the browbones, the glabella, the occiput, the shape of the mandible (body and ramus), and the size of the pelvic acetabulum indicate the male sex of the deceased.

The occiput is prominent, and the so-called occipital bun, characteristic of the Mediterranean type, is evident.

The preserved postcranial skeleton of the adult comprises the following: one fragment of the spinous process of a vertebra, a collarbone (submitted for examination), the right humerus $(333 \mathrm{~mm})$, the right ulna $(273 \mathrm{~mm})$, the right radius $(256 \mathrm{~mm})$, the shaft of the left humerus, the left ulna $(277 \mathrm{~mm})$, the left radius $(248 \mathrm{~mm})$, bones of the wrist, metacarpus, and fingers, a small fragment of a rib, fragments of the right and left pelvis (the left one with the acetabulum), the right $(473 \mathrm{~mm})$ and left femur $(472 \mathrm{~mm})$, the right and left patella, the right $(394 \mathrm{~mm})$ and left $(389 \mathrm{~mm})$ tibia, the left fibula $(373 \mathrm{~mm})$, a shaft fragment of the right fibula, the right talus bone, the right and left calcaneus, and bones of the metatarsus and toes. The lengths in parentheses are the maximum lengths of the best-preserved bones.

Based on the measurements of the available long bones, the height in life of the examined individual was 173-177 cm (based on: TrOTTER, GLeSER 1952). 


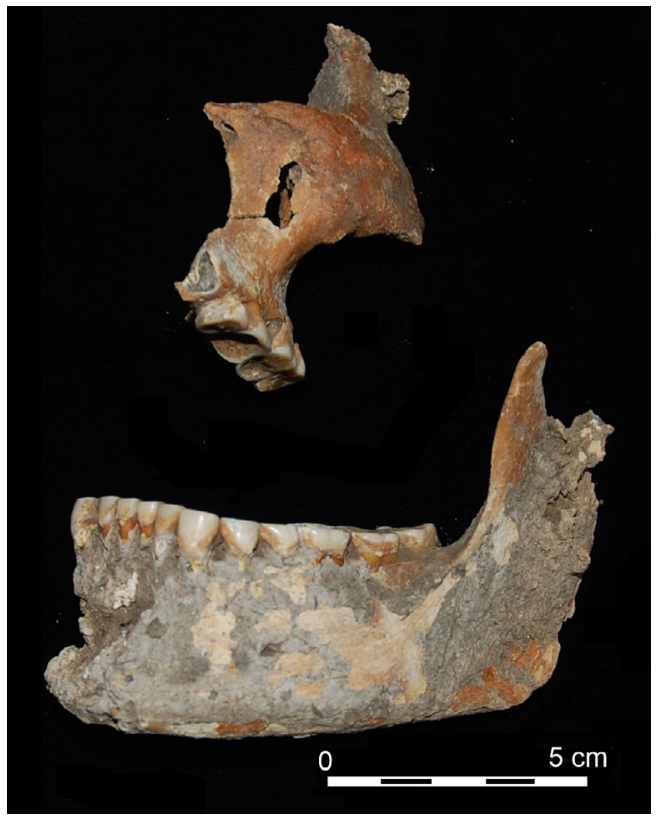

Fig. 8. Węgrzce, Kraków district, site no. 3. Feature no. 3/2016. Fragment of jaw and mandible of the maturus individual (photo by B. Musiał-Łaczek)

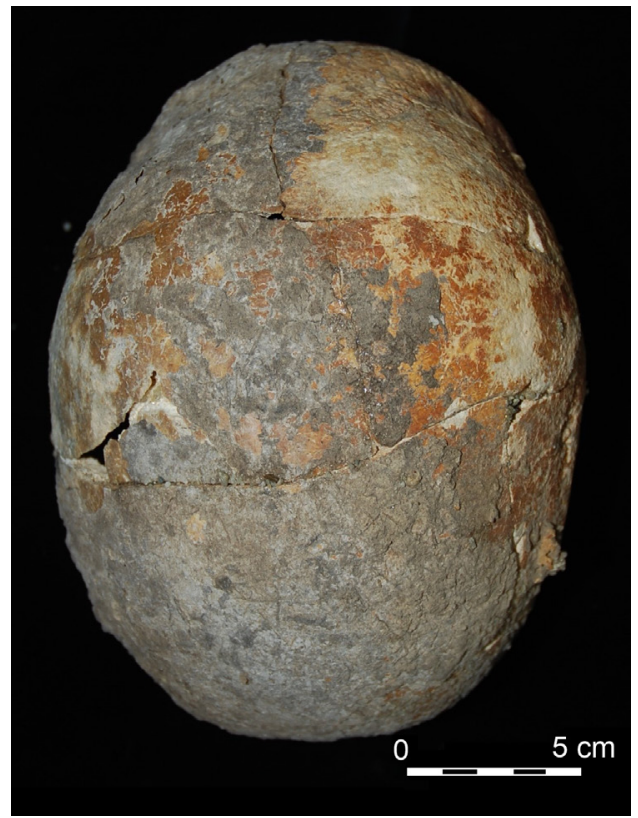

Fig. 9. Węgrzce, Kraków district, site no. 3. Feature no. $3 / 2016$. The skull of adult individual in norma parietalis (photo by B. Musiał-Łaczek)

The child's skeleton survived in poor condition. The preserved elements include the following: four small fragments of the skull and loose deciduous teeth: three incisors, three canines, and molars. The preserved loose buds of the upper permanent teeth are: I1, I2 (incisors), C (canine), M1, M2 (molars). The buds of the lower permanent teeth are: I1 (incisor), C (canine) (Fig. 10).

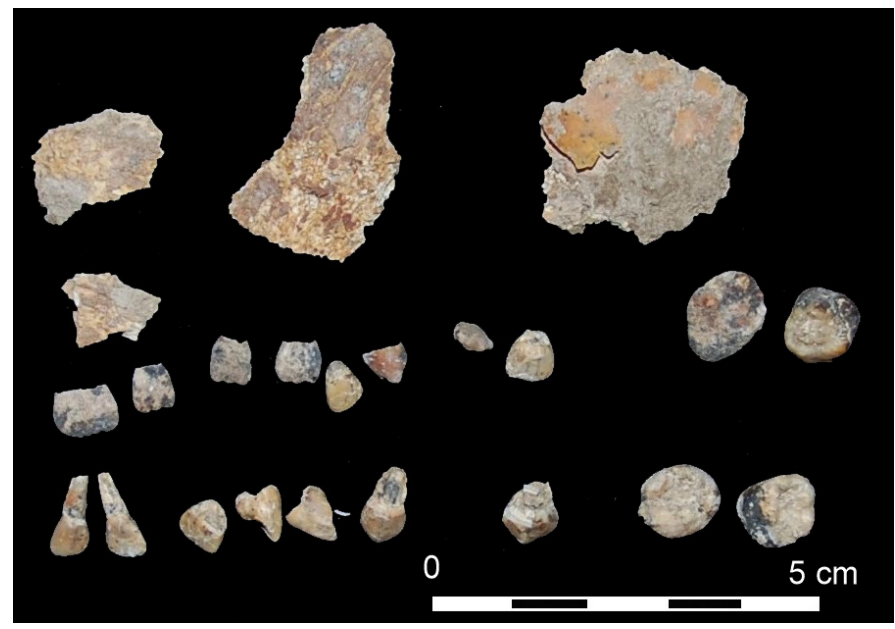

Fig. 10. Węgrzce, Kraków district, site no. 3. Feature no. 3/2016. Fragments of skull, preserved fragments of toothing and tooth buds, which belonged to infans I individual (photo by B. Musiał-Łaczek) 
The preserved fragments of the child's postcranial skeleton include the following: a fragment of a collarbone, two shaft fragments of a radius, a shaft fragment of a femur with the inferior epiphysis, fragments of the proximal epiphysis and shaft of tibia and fibula, and a fragment of a patella. The epiphyses of the analysed bones are not fused with the shafts. The age was determined as infans I (about 4-5 years), on the basis of the degree of eruption of the teeth and the preserved buds of permanent teeth (UMBELAKER 1989)

\section{TAXONOMICAL AND CHRONOLOGICAL REMARKS}

The site where grave $3 / 2016$ was discovered lies within the loess uplands of western Lesser Poland, towering from the west over the lower Dłubnia valley. Within a radius of $2 \mathrm{~km}$, three other CWC graves are known: Bosutów, site 9 (see footnote 1; KIRKOR 1881); Bosutów, site 11 (Krauss 1960); and Batowice, site I (NoseK 1947). ${ }^{4}$ Late Neolithic sepulchral complexes at site 5 in Modlnica (WŁodArCZAK et al. 2011) and in Kraków-Wzgórza Krzesławickie (including sites 21, 22 and 47; ZemeŁKa 1959; SochaCKI 1964; Kogus 1969) are also relatively close.

The construction of the grave is difficult to determine due to the significant erosion of the site. As a result, only the lower part of the grave was recorded. Analogies from other sites in Lesser Poland allow us to assume that a niche structure was used - a solution prevailing in cemeteries in south-eastern Poland. This is suggested by the oval shape of the grave and the arrangement of human remains, indicating the body was decaying in an empty chamber (DUDAY 2009: 32-38). The dark sediment recorded in the lower part of the grave indicates that the niche ceiling did not collapse rapidly, but dark humic earth gradually washed in from the side of the entrance to the burial chamber.

Double burials are a constant feature of CWC cemeteries: 38 have been discovered so far in the Kraków-Sandomierz group (number of features: 346). Among them there are also burials of an adult man with a child, just like in the grave from Węgrzce. Particularly noteworthy in this context are richly furnished burials of men, with stone battle axes, who also have a child or children buried with them: from grave 67 in Żerniki Górne (Kempisty, WŁodARCZAK 2000: 35-36), grave 1307 in Kraków-Mistrzejowice (JAROSZ et al. 2015: 168), ${ }^{5}$ and grave 2 in Gabuttów (burial of a man and two children; GóRSKI, JAROSZ 2006: 407-413). Currently, it is difficult to interpret this manifestation of funeral rituals, which might reflect a "partnership" arrangement of the deceased in the grave or possibly child burials of sacrificial nature. A significant number of graves holding burials of two deceased (less frequently also three and four deceased) may point to unnatural causes of deaths in the case of all or some of the people buried there. Usually, they are simultaneous burials, although there are also cases known of reusing a burial niche in order to add another deceased.

\footnotetext{
4 In fact: Dziekanowice, site 5 (verified by J. Górski and M. Zając during surface surveys of AZP area 101-57).

5 In this case, the sex of the older individual was anthropologically determined as female, although the position and orientation of the body, as well as the nature of the grave goods, suggest a male (JAROsz et al. 2015: 169).
} 
The characteristics of the discovered grave goods indicate that they were intended for the adult individual (male). A large beaker and a stone battle axe are the basic elements. The artefacts discovered in the grave also included tools (a bone tool and a flake insert of a knife), and flint blanks.

The beaker from the grave in question is a vessel typical for grave inventories from the Kraków region. Its diagnostic features are a medium-high funnel-like neck, ovoid belly, and the absence of a foot. Thus, the vessel should be classed as variant $\mathrm{Vb}$ (MACHNIK 1966: 28, 29), or variant PVBd (WŁoDARCZAK 2006a: 231, pl. IX). These are forms characteristic of the territory between the Dłubnia and the Szreniawa, known primarily from the Nowa Huta inventories (WŁODARCZAK 2006a: 109-110). Another characteristic element is the decoration made with s-twisted cord impressions. It consists of a band of horizontal lines and a "geometric" motif below, the latter combining a chevron ornament (above) with a zigzag (below). Typological analogies are known from the immediate vicinity, formally the closest analogies being beakers from grave 229 in Kraków Nowa Huta Zesławice (ZemeŁKa 1959: pl. I: 1; WeOdARCZAK 2006a: 324, pl. CII: 3), grave 29 in Kraków-Mistrzejowice (Jarosz, MianowsKa 2011: 253, fig. 11: 1), and grave 1 in Sulechów (BARTYS 1937: 97, fig. 2: 1). A beaker from grave 3 in the neighbouring site 11 in Bosutów is also close in form, although its decoration differs slightly (KraUss 1960: 63, fig. 8; WŁODARCZAK 2006a: 323, pl. CI: 7). The vessel from Węgrzce belongs to a group of finds with a clearly defined shape and specific ornamentation, characteristic of the area near Kraków. This stylistic homogeneity of the finds suggest interpreting them as an expression of the continuity of tradition, and of belonging to one specific human group who economically exploited an area of a size of a microregion (MACHNIK 2009: 216). The "Batowice" beakers (MACHNIK 1966; WŁODARCZAK 2006a), to which the vessel from grave 3/2016 in Węgrzce belongs, are especially characteristic of the zone between Kraków and the Szreniawa, although they also occur less frequently in the northern part of the western Lesser Poland loess upland.

Another typologically diagnostic artefact is the stone battle axe discovered by the left shoulder of the deceased (a place characteristic for this type of finds). It is a slender form with an asymmetric blade, which can be considered a derivative of early Corded battle axes, in particular of those of the Ślęża type (cf. Libera, SobIERAJ 2019: 337, fig. 1: g). The artefact was classed as type F (WŁODARCZAK 2006a: 35), i.e. having the hole moved towards the blade. A characteristic feature of these battle axes is the careful flattening of the upper surface (sometimes also the lower one). In south-eastern Poland, battle axes of this type are characteristic of grave inventories from the western Lesser Poland loess upland. More precisely, most of them come from loess areas between the Dłubnia and the Szreniawa, i.e. from the vicinity of the site discussed here. Similar specimens were discovered in Bosutów (grave 3; Krauss 1960: 66, fig. 9: 1; WŁodarCZAK 2006a: 323, pl. CI: 9), Proszowice (grave 2; Prokopowicz 1966: pl. II: 2; WŁodarCZAK 2006a: 272, pl. L: 6), and Sulechów (grave 1; BARTYs 1937: 97, fig. 2: 3; MACHNIK 1966: pl. III: 1b).

The specimen from Węgrzce represents certain features of battle axes of the $F$ type: a typological proximity to the Ślęża battle axes, and the selective choice of raw material, coming down to choosing fine-grained crystalline rocks of green or blue colour. 
This second feature may be related to the first one, assuming the provenance of these raw materials from the Sudeten region is confirmed. So far, however, the western origin of battle axes from Lesser Poland has not been confirmed by specialist analyses. In the case of serpentinite artefacts, such an origin is often assigned automatically. A western origin is also suggested by the typological similarity between artefacts from Lesser Poland and Lower Silesia (e.g. WoJCIECHOWSKi 1988).

The flint knife insert is a typical component of grave inventory in CWC male burials. These tools were usually made on blades, using a selectively chosen raw material (with chocolate flint prevailing in western Lesser Poland). The insert from the grave discussed here is small. It was made on a small flake, and the working part was retouched flat on the positive side. Despite these rare features, the insert was suitable for mounting in a short knife handle typical of the Final Eneolithic.

The poorly preserved bone tool represents a type of massive awl, wedge, or perforator, rarely found in CWC graves in Lesser Poland. Recently, a rich inventory from grave 15 in Wilczyce in the Sandomierz Upland has provided several similar artefacts (Boroń 2019: 132, fig. 2: 1 and 136, fig. 6: 3-5). A similar tool also comes from the nearby grave 1307 in Kraków Mistrzejowice (JAROsZ et al. 2015: 171, fig. 5: 4). It was probably a kind of punch, akin to a narrow-edged chisel, used primarily in the processing of flint. Thus, it is also a tool characteristic of male burials.

In general, the set of artefacts from the grave in Węgrzce is modest when compared to the standard furnishings of the burials of men placed on the right side known from the western Lesser Poland loess upland. The set lacks one characteristic piece, namely an axe, and the toolkit is limited to only two items (knife insert and bone awl). No set of arrowheads or ornaments were deposited either. However, such a funeral ritual is not unique: poorly furnished burials of men on the right side are known from all regions of Lesser Poland. Moreover, no particularly richly furnished graves have been discovered in the Kraków region (on the lower Dłubnia) to date, like those from other areas of western Lesser Poland. As it seems, this can only partly be explained by the accidental nature of most of the discoveries and the rescue nature of the research.

In light of the above observations, the taxonomic and chronological assessment of grave 3/2006 raises no doubts: it is a feature associated with the Batowice subgroup and dated to sub-phase IIIB, the younger stage of the CWC development in western Lesser Poland. The arrangement of the body, as well as the characteristics of the grave goods (especially of the beaker and the stone battle axe) find very good analogies at nearby sites, e.g. in Batowice, Bosutów, Kraków Nowa Huta Zesławice (sites 21 and 22), Kraków Mistrzejowice, and Sulechów.

\section{RADIOCARBON DATING}

Radiocarbon AMS dating was performed at the Poznań Radiocarbon Laboratory, using a sample from the adult's bone. The result was 3930 \pm 30 BP (Poz-90774). Using the OxCal v4.4.2 program (Ch. Bronk Ramsey from 2020) and the INTCAL20 
calibration curve (REIMER et al. 2020) we obtain the calendar age range of 24712348 BC (68.2\% probability - Fig. 11). This corresponds to the dating of the classic assemblages of the Kraków-Sandomierz group of the CWC, i.e. to sub-phase IIIB (WŁODARCZAK 2006a: 127).

The above result is similar to the results of AMS dating obtained for richly furnished burials of men with pottery of the "Kraków type": grave 10 from tomb 2 in Malżyce (3940 \pm 40 BP; JAROSz et al. 2009: 209, table 2), grave 1 from Smroków (3950 \pm 40 BP; WŁODARCZAK 2006b: 390, table 1), or grave 3 in Zielona $(3955 \pm 35$ BP; WŁodARCZAK 2006a: 125, table 35). Only a slightly older result was obtained for a similar grave, XI-B1 from Bronocice (4000 \pm 40 BP: KRUK et al. 2018: 21 , table 4). The date obtained for grave $7 / 54$ from Kraków Nowa Huta Zesławice, site 22 (Ki-7948: 4150 \pm 80 BP; TUNIA, WŁODARCZAK 2002: 50, 51) clearly stands out in this context. It points to the older phase of CWC, a range around 2800-2600 BC (in terms of the typological traits of the grave goods and the burial itself, this grave links with the late phase, like the grave from Węgrzce). However, in the light of the verification of some age determinations obtained in the Kyiv laboratory with newer methods, this date seems unreliable ( $c f$. WŁODARCZAK 2008: 109, 110).

The ${ }^{14} \mathrm{C}$ date obtained for grave 3/2016 from Węgrzce is the first high-precision absolute age determination obtained from the relatively rich cluster of CWC cemeteries in the lower Dhubnia basin (= cluster A or the Batowice subgroup according to WŁODARCZAK 2006a). This date indicates that, as predicted, these cemeteries are associated with the late stage of CWC development, sub-phase IIIB (ca. 2500-2400/2300 BC).

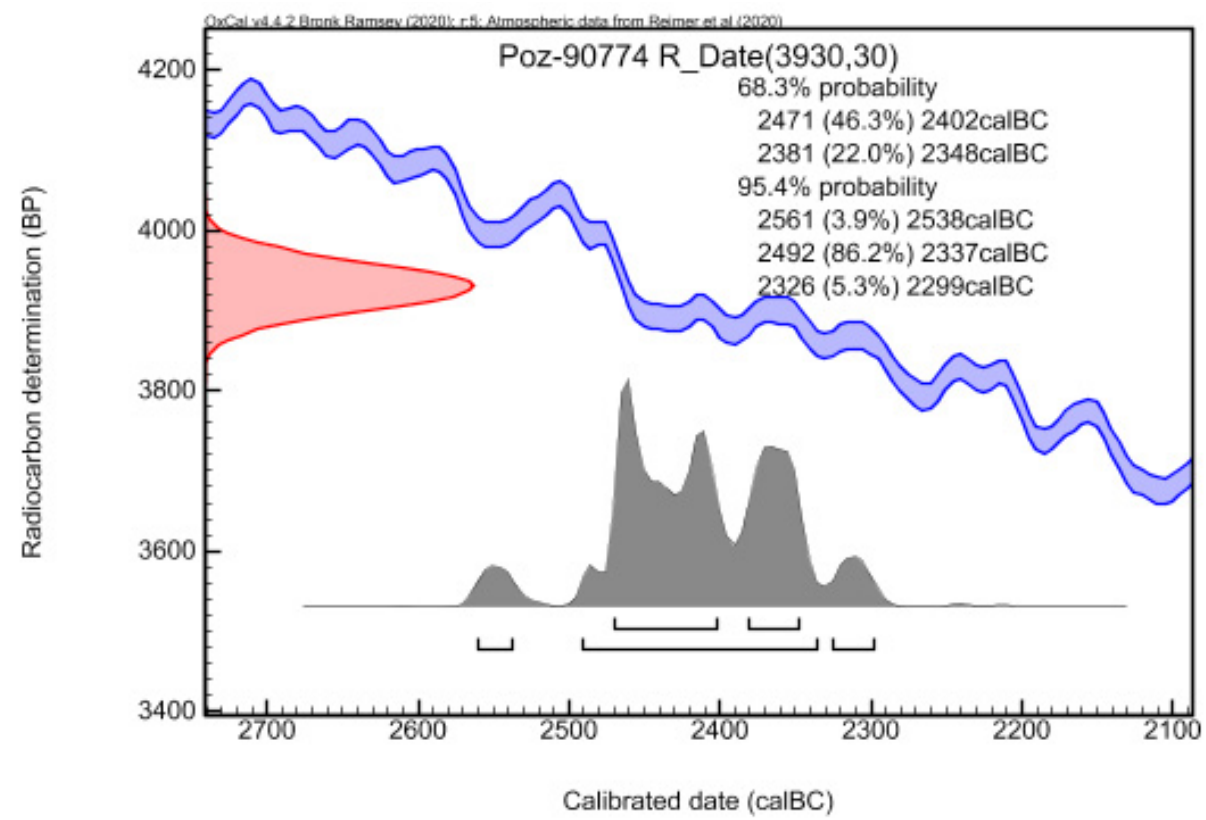

Fig. 11. Węgrzce, Kraków district, site no. 3. Feature no. 3/2016. Calibration graph of radiocarbon dating made for human bone of an adult person (program OxCal v4.4.2 by Ch. Bronk Ramsey in 2020) 


\section{CONCLUSIONS}

The rescue research carried out at site 3 in Węgrzce resulted in documenting a sequence of settlement episodes dated to the Stone Age and the Bronze Age. One of its elements is a cemetery from the younger phase of CWC, represented by grave 3/2016 discussed above. Most probably, it confirms the presence of a cluster of sepulchral features occupying the plateau part of the loess hill. The examined burial represents a rite characteristic of the Kraków-Sandomierz group of CWC in the lower Dłubnia basin. Its closest analogies come from the nearby sites in Batowice and Bosutów, and from Wzgórza Krzesławickie in Kraków. Together with the neighbouring finds, site 3 in Węgrzce forms a complex of small cemeteries of several graves, established by the local Final Eneolithic community around 2500-2300 BC.

ACKNOWLEDGEMENTS. The radiocarbon date was obtained within the framework of the "Final Neolithic communities in south-eastern Poland in light of archaeological research and interdisciplinary analyses" project led by Anita Szczepanek (grant from National Science Centre, OPUS no. 2015/19/B/HS3/02149).

\section{REFERENCES}

BARTYS J., 1937. Nowe stanowiska małopolskiej grupy ceramiki sznurowej. Wiadomości Archeologiczne 6: $96-99$.

Boroń T., 2019. Wytwory kościane i rogowe. In: P. Włodarczak (Ed.), Wilczyce, stanowisko 10. Norma i precedens w rytuale pogrzebowym małopolskiej kultury ceramiki sznurowej. Kraków-NiepołomicePękowice, Instytut Archeologii i Etnologii PAN - Wydawnictwo i Pracownia Archeologiczna ProfilArcheo - Stowarzyszenia Archeologów Terenowych STATER: 131-138.

Brothwell D., 1967. The bio-cultural background to disease. In: D. Brothwell, A.T. Sandison (Eds), Diseases of Antiquity. Springfield, IL, Charles C. Thomas: 56-68.

DudAY H., 2009. The archaeology of the dead. Lectures in archaeothanatology. Oxford, Oxbow Books.

Gilewska S., Starkel L., 1980. Rzeźba miejskiego województwa krakowskiego. Series Geographicaphysica 13: 33-49.

Górski J., JARosz P., 2006. Cemetery of the Corded Ware and the Trzciniec cultures in Giebułtów. Sprawozdania Archeologiczne 58: 403-457.

Jarosz P., Mianowska I., 2011. The Corded Ware culture cemetery in Kraków-Mistrzejowice. Sprawozdania Archeologiczne 63: 241-276.

Jarosz P., Tunia K., WŁodarczak P., 2009. Burial mound no. 2 in Malżyce, the district of Kazimierza Wielka. Sprawozdania Archeologiczne 61: 175-231.

Jarosz P., Koszowska E., Ostrowski M., SzczePanek A., 2015. Niche burials of the Corded Ware Culture at Kraków-Mistrzejowice, site 85. Sprawozdania Archeologiczne 67: 165-187.

Kempisty A., Wıodarczak P., 2000. Cemetery of the Corded Ware Culture in Żerniki Górne. Światowit Supplement Series P 5. Warsaw: Institute of Archaeology, Warsaw University.

KiRKOR H., 1881. Sprawozdanie i wykaz zabytków złożonych w Muzeum A. U. z wycieczki archeologicznej w roku 1880. Zbiór Wiadomości do Antropologii Krajowej 5: 9-17. 
Kogus A., 1969. Grób kultury ceramiki sznurowej ze Wzgórz Krzesławickich (Nowa Huta). Wiadomości Archeologiczne 29: 86.

Kondracki J., 2002. Geografa regionalna Polski. Warszawa, Wydawnictwo Naukowe PWN.

Krauss A., 1960. Cmentarzysko kultury ceramiki sznurowej w Bosutowie, pow. Kraków. Materiały Archeologiczne 2: 61-67.

Kruk J., Milisauskas S., WŁodarczak P., 2018. The real time. Radiocarbon dates and Bayesian analysis of the Neolithic settlement at Bronocice, fourth millennium BC. Kraków, Instytut Archeologii i Etnologii PAN.

Libera J., SobieraJ J., 2019. O toporach ślężańskich/śląskich/sobotczańskich kilka uwag z oddali. In: M. Szmyt, P. Chachlikowski, M. Ignaczak, P. Makarowicz (Eds), VIR BIMARIS. Od kujawskiego matecznika do stepów nadczarnomorskich. Studia z dziejów międzymorza bałtycko-pontyjskiego ofiarowane Profesorowi Aleksandrowi Kośko. Archaeologia Bimaris. Dyskusje 5. Poznań, Uniwersytet im. Adama Mickiewicza w Poznaniu, Instytut Archeologii, Zakład Prahistorii Europy Środkowo-Wschodniej: 335-348.

MACHNIK J., 1966. Studia nad kulturą ceramiki sznurowej w Małopolsce. Wrocław-Warszawa-Kraków, Zakład Narodowy im. Ossolińskich.

MACHNIK J., 2009. Short and long-distance pastoral journeys along ancient upland routes in Europe in the $3^{\text {rd }}$ millennium BC. Baltic-Pontic Studies 1: 214-222.

NoSEK S., 1947. Nowoodkryte stanowiska krakowskiej grupy ceramiki sznurowej. Sprawozdania z posiedzeń Komisji Archeologicznej PAU 48: 273-277.

Prokopowicz J., 1966. Nowe neolityczne stanowisko w Proszowicach. Materiały Archeologiczne 7: 79-85.

SochACKi Z., 1964. Grób kultury ceramiki sznurowej w Dłubni-Zesławicach pod Krakowem. Wiadomości Archeologiczne 30(3/4): 317-321.

Trotter M., Gleser G. C., 1952. Estimation of stature from long bones of American Whites and Negroes. American Journal of Physical Anthropology 10: 463-514.

Tunia K., Wıodarczak P., 2002. Radiocarbon Results for the Corded Ware Culture from southern Poland. Przegląd Archeologiczny 50: 45-55.

Reimer P., Austin W., Bard E., Bayliss A., Blackwell P., Bronk Ramsey C., Butzin M., Cheng H., Edwards R., Friedrich M., Grootes P., Guilderson T., Hajdas I., Heaton T., Hogg A., Hughen K., Kromer B., Manning S., Muscheler R., Palmer J., Pearson C., van der Plicht J., Reimer R., Richards D., Scott E., Southon J., Turney C., Wacker L., Adolphi F., Büntgen U., Capano M., Fahrni S., Fogtmann-Schulz A., Friedrich R., Köhler P., Kudsk S., Miyake F., Olsen J., Reinig F., Sakamoto M., Sookdeo A., Talamo S., 2020. The IntCal20 Northern Hemisphere radiocarbon age calibration curve (0-55 cal kBP). Radiocarbon 62, DOI https://doi.org/10.1017/RDC.2020.41.

Umbelaker D. H., 1989. Human skeletal remains. Excavation, analysis, interpretation. Washington, Taraxacum.

WŁodARCZAK P., 2006a. Kultura ceramiki sznurowej na Wyżynie Małopolskiej. Kraków, Instytut Archeologii i Etnologii PAN.

WŁodARCZaK P., 2006b. Cemetery of the Corded Ware culture at site 17 in Smroków, Słomniki commune, district of Kraków. Sprawozdania Archeologiczne 58: 377-399.

WŁodARCZAK P., 2008. Archaeological interpretation of dendrochronological and radiocarbon dates. An example of Corded Ware culture. Archaeological culture versus chronology. Sprawozdania Archeologiczne 60: 103-128.

WŁodarczak P., 2020. Schyłek eneolitu w okolicach Krakowa Nowej Huty. Materiały Archeologiczne Nowej Huty 26: 39-64. 
Wlodarczak P, Zastawny A., Grabowska B., 2011. Groby kultury ceramiki sznurowej i kultury mierzanowickiej ze st. 5 w Modlnicy, pow. krakowski. In: J. Kruk, A. Zastawny (Eds), Modlnica, st. 5. Od neolitu do wczesnej epoki brązu, Via Archaeologica. Źródła z badań wykopaliskowych na trasie autostrady A4 w Małopolsce. Kraków, Krakowski Zespół do Badań Autostrad: 291-410.

Wojciechowski W., 1988. Próba lokalizacji ośrodków produkcyjnych toporów ślężańskich w świetle badań petroarcheologicznych. Przegląd Archeologiczny 35: 101-138.

ZemęKa S., 1959. Groby kultury ceramiki promienistej i sznurowej w Zesławicach, pow. Kraków (Nowa Huta). Materiały Archeologiczne 1: 85-90. 